\title{
Hilbertova aritmetizace geometrie
}

\author{
Jan Zeman \\ Fakulta filozofická \\ Západočeská univerzita v Plzni \\ Jungmannova 1, 30614 Plzeň \\ janzeman@email.cz
}

Tato práce se podrobně věnuje způsobu, jakým David Hilbert (1862-1943) pojal aritmetizaci geometrie v knize Grundlagen der Geometrie z roku 1899. Nejprve stručně představíme Hilbertovy předchůdce z téže doby konce 19. století, kteří bud' volali po změnách v založení geometrie, nebo je již sami zapracovali prostřednictvím axiomaticko-deduktivní metody. Přitom zároveň zmíníme relevantní Hilbertovy přednášky z oboru geometrie, které jeho dílu předcházely. Následně se pokusíme nastínit obsah prvních dvou kapitol knihy a vysvětlit dobové i věcné souvislosti, nutné k jejich pochopení. Představíme způsob implicitních definic základních pojmů a vztahů v axiomech a dále Hilbertovo rozdělení axiomů do skupin, přičemž se zejména zaměříme na axiomy spojitosti v kontextu s problematikou bezespornosti geometrie. K tomu popíšeme konstrukci aritmetického modelu axiomů geometrie, který Hilbert pro důkaz bezespornosti používá. V závěru se pokusíme nastínit Hilbertovy hlavní důvody k napsání díla a některé klíčové důsledky jeho pojetí axiomatiky geometrie.

\section{Úvod}

V tomto článku představíme způsob, jakým David Hilbert (1862-1943) sleduje myšlenku aritmetizace geometrie prostřednictvím její nové axiomatiky v knize Grundlagen der Geometrie z roku 1899. Nejdřive jmenujeme Hilbertovy předchůdce, kteří se o novou axiomatizaci geometrie pokoušeli, a zmíníme i jeho činnost $\mathrm{v}$ oboru geometrie před vydáním knihy. Autory, kteří axiomatizovali aritmetiku a logiku, zde neuvádíme, nebot’ jde o rozsáhlé téma mimo záběr článku. 
Následně provedeme textovou analýzu prvních dvou kapitol knihy za použití následující sekundární literatury: Nejvíce budeme používat záznamy Hilbertových přednášek o geometrii a napojení na literaturu, kterou Hilbert četl, uvedené v disertaci Michaela Toepella z roku 1986 o původu tohoto Hilbertova díla. Některé interpretace z oboru filosofie matematiky budou převzaty z knihy od Romana Murawského a Thomase Bedürftiga a z knihy Petra Vopěnky a Marie Větrovcové. Současné interpretace budeme citovat z knihy editora Hanse N. Jahnkeho a knihy editora Williama Ewalda. Dále budeme vycházet z primárních zdrojů v Hilbertových Gesammelte Abhandlungen, a to především z Hilbertova životopisu od Otta Blumenthala (1876-1944). Hilbertovo pojetí se pokusíme srovnat s postojem Henriho Poincarého (1854-1912) a Richarda Dedekinda (1831-1916), pro tento účel užijeme aktuální české vydání Poincarého textů a francouzské kritické vydání spisů Dedekindových. ${ }^{1}$

Pokusíme se předložit takový výklad, který by pomohl nováčkovi se $\mathrm{v}$ textu orientovat. K textu doplňujeme kontext Hilbertových názorů, jím neuvedené souvislosti matematické a historické, které se budeme snažit dokázat na primárních textech. Zaměříme se přitom na způsob, jakým Hilbert chápe aritmetizaci geometrie, a rozebereme aritmetický model, který ve druhé kapitole používá k důkazu bezespornosti. Hilbertův text zde doplníme konkrétními př́klady či protipř́iklady, kterými se budeme snažit vyjasnit souvislost problému bezespornosti geometrie s problémem její spojitosti.

V závěru uvedeme názory několika Hilbertových současníků na důvody, proč Hilbert dílo psal, a porovnáme je se současnou standardní interpretací textu, což bude druhým cílem naší studie.

\section{Předchůdci - názornost geometrie, počátky bezespornosti}

Již delší dobu před Hilbertem bylo mezi matematiky známo, že Eukleidovy Základy obsahují jisté nedostatky. Šlo např. o skutečnost, že některé jeho axiomy bylo možné odvodit z jiných, že množina axiomů nebyla

1 Toepell (1986). Bedürftig \& Murawski (2015). Vopěnka \& Větrovcová (2015). Jahnke (1999). Ewald (2006). Hilbert (1970). Blumenthal (1970). Fiala (2010a). Benis-Sinaceur (2008). 
nejmenší možná, že některá jeho tvrzení měla být naopak označena za axiomy, že ve svých důkazech neuvedl všechny předpoklady, které používal, nebo že některé z nich nebyly v díle ani přítomny, at’ už jako axiomy či jako tvrzení. V druhé polovině 19. století se navíc zpětně objevil problém spojitosti geometrie. ${ }^{2}$

Důkazy nezávislosti pátého Eukleidova postulátu, díky kterým byly v první polovině 19. st. objeveny neeukleidovské geometrie, odpovídají důkazům bezespornosti těchto geometrií. Felix Klein (1849-1925), který ve svém Erlangenském programu neeukleidovské geometrie klasifikoval, dokázal bezespornost neeukleidovské geometrie hyperbolické pomocí modelu, ve kterém identifikoval její prvky a vztahy s určitými prvky a vztahy geometrie eukleidovské. ${ }^{3}$ Nabízela se ihned otázka, zda by mohl být proveden podobný důkaz bezespornosti těch geometrií, které by vycházely z absence jiných předpokladů než zrovna pátého Eukleidova postulátu o rovnoběžkách. ${ }^{4}$ Pokud ano, bylo by tím též dokázáno, že tyto axiomy a postuláty nejsou nutné pro to, aby byla výsledná geometrie bezesporná, a že jsou tedy nezávislé. ${ }^{5}$ Mezi takto vzniklými geometriemi by tak eukleidovská geometrie ztratila jakékoliv výsadní postavení a nedostačoval by ani Eukleidův způsob vedení důkazů po-

2 Jde o otázku, zda Eukleidovy axiomy vynucují, aby prostor obsahoval nutně všechny body. Problém se projeví hned při prvním Eukleidově tvrzení první knihy Základů, ve kterém Eukleidés stanovuje úlohou, že lze zkonstruovat rovnostranný trojúhelník, aniž by v důkaze uvedl předpoklad, že se dvě kružnice se středy v krajních bodech úsečky, jejichž poloměrem je délka této úsečky, musejí nutně protnout, tj. že body protnutí existují. Eukleidés tento předpoklad neuvedl, což však nebylo chybou, ale souviselo s jiným chápáním geometrického důkazu v antice, totiž jakožto poukazu k evidenci. Budoucí změnu v pojetí geometrických důkazů předznamenal Bernard Bolzano (1781-1848), jenž u tohoto tvrzení upozornil, že evidovaná pravda o protnutí dvou kružnic při konstrukci rovnostranného trojúhelníku je až objektivním důsledkem objektivní pravdy, že prostor body protnutí obsahuje. Viz Večerka (1967, s. 211). V Hilbertově době na nespojitost Eukleidovy geometrie upozornil Dedekind v dopise Lipschitzovi z roku 1876. Viz Dedekind (1876, s. 479); srov. komentář Benis-Sinaceur (2008, s. 273-281).

3 Viz Klein (1871). Klein (1873). Požadavek důkazu bezespornosti geometrie eukleidovské matematikové nevznášeli, nebot její bezespornost dokazoval názor samotný.

4 Klein v článku použíá nejprve termín předpoklady (Voraussetzungen), následně již jen axiomy. Pod tento termín však zahrnuje i Eukleidovy postuláty, nebot mluví např. výslovně o axiomu o rovnoběžkách (pátý postulát) či axiomu o nekonečné přímce (první postulát). Viz Klein (1873, s. 113).

5 Toto pojetí nezávislosti tvrzení (tj. i axiomů a postulátů) je třeba odlišit od druhého případu, kdy říkáme, že axiom je nezávislý na ostatních, pokud jej z ostatních nelze odvodit. Pokud potom jsou takto vzájemně nezávislé všechny axiomy daného systému, neobsahuje tento systém nadbytečné axiomy. Viz Weyl (1944, s. 266); srov. Toepell (1986, s. 59). 
mocí přivedení k evidenci, což většina matematiků, včetně těch, kteří zmíněné neeukleidovské geometrie uznávali, již nebyla ochotna přijmout. 6

Klein navrhoval vytvořit nový systém axiomů nejprve pro projektivní geometrii, která v jeho pojetí všechny tyto metrické geometrie zahrnovala. Přidáním dalších axiomů by pak tyto další geometrie bylo možné vyčlenit. Zároveň, bráno z druhé strany, by pak např. pro systém axiomů eukleidovské geometrie platilo, že pokud bychom vzali jen jeho podmnožinu, bylo by z ní možné odvodit opět pouze určitou podmnožinu ze všech tvrzení eukleidovské geometrie. ${ }^{7}$

Kleinem navržená axiomatika se poprvé objevila v knize Vorlesungen über neuere Geometrie z roku 1882 od Moritze Pasche (1843-1930), který se v ní na Kleina přímo odkazoval. Pasch řešil některé zmíněné výtky $\mathrm{k}$ Eukleidovu dílu. Jeho axiomy, které nazýval základní věty (Grundsätze), již představovaly množinu, z níž šla všechna ostatní tvrzení přísně logicky odvodit. Tato množina zahrnovala např. i axiomy uspořádání či axiom spojitosti, které v Základech scházely, a na druhou stranu v ní žádný axiom nebyl nadbytečný. Ačkoliv Pasch pro základní pojmy, o nichž jeho axiomy vypovídaly, tj. pro body, úsečky a části roviny, již uznával nejednoznačnost interpretace, měly tyto pojmy stejně jako u Eukleida stále empirický původ. ${ }^{8}$ Zcela abstraktní, tj. na zkušenosti nezávislé, byly teprve základní pojmy v axiomatizaci geometrie Giuseppe Peana (1858-1932) z roku 1889, která představovala pouhý logický kalkul, a to v Peanově specifické symbolice, kde byly tyto základní nedefinované pojmy, tj. u Peana jen body a úsečky, reprezentovány proměnnými. Ve své pozdější práci z roku 1894 navíc Peano požadoval důkazy vzájemné nezávislosti všech axiomů. ${ }^{9}$

Hilbert ve svých Grundlagen der Geometrie přímo odkazoval na knihu Paschovu. Na Peana se zde neodvolával, ale o jeho činnosti věděl a např. ve svých přednáškách z roku 1898 odkazoval na jinou Peanovu práci $\mathrm{k}$ axiomatizaci geometrie. Své přesvědčení, že je matematicky

6 Poincaré (1903, s. 2).

7 Srov. Toepell (1986, s. 7).

8 Ani Pasch proto nepokládal otázku o bezespornosti svého systému axiomů, nebot’ ji stejně jako u Eukleida zaručoval názor.

9 Peano (1889). Peano (1894). 
nevýznamné, zda geometrické pojmy vycházejí z názoru či nikoliv, a že má smysl přemýšlet pouze o jejich spojení prostřednictvím axiomů, však převzal především z přednášky, kterou na sjezdu německých přírodovědců roku 1891 v Halle přednesl Hermann Wiener (1857-1939). Ten v ní navrhoval stanovit celý nový systém axiomů abstraktních a zcela se vyhnout $\mathrm{v}$ té době dominujícím Paschovým empirickým axiomům geometrie. $^{10}$

Hilbertova činnost v oboru geometrie počínala vedením přednášek o geometrii projektivní v roce 1891 a o geometriích neeukleidovských v roce 1894. Výsledky svých výzkumů shrnul v dopise Kleinovi z téhož roku, kde Hilbert pojednával o přímce jako nejkratší spojnici dvou bodů. Publikace tohoto dopisu z roku 1895 je zároveň Hilbertovou první prací z oboru geometrie. ${ }^{11}$ Po letech, kdy se věnoval teorii čísel, se ke geometrii vrátil v přednáškách v zimním semestru 1898/1899, a to nyní ke geometrii eukleidovské. ${ }^{12}$

\section{Hilbertovy Grundlagen der Geometrie}

Na začátku díla Grundlagen der Geometrie zavádí Hilbert své základní pojmy - body, přímky a roviny - jako tři různé systémy věcí (Systeme von Dingen). Toto sousloví použil již před ním Dedekind, přičemž slovo systém užíval v tomtéž významu jako množina a věc definoval jako „předmět našeho myšlení“ (Gegenstand unseres Denkens). ${ }^{13}$ To mělo i u Hilberta, v souladu s jím zamýšlenou radikální abstrakcí od názoru, vyjádřit, že zavedené pojmy nenesou od začátku tentýž standardní význam, který nesou v obyčejném jazyce. Určitý konkrétní význam získávají až skrze jednotlivé axiomy, které mezi těmito pojmy zavádějí vztahy, což komentoval jeho současník, matematik a fyzik Henri Poincaré takto:

10 Viz Blumenthal (1970, s. 402f); srov. Toepell (1986, s. 40ff).

11 Hilbert (1895).

12 V dopise Adolfovi Hurwitzovi (1859-1919) z 16. 3. 1898 se Hilbert vyjádřil, že kvůli tomu, že byla veškerá pozornost upřena na axiom o rovnoběžkách a příslušné geometrie neeukleidovské, byla eukleidovská geometrie zanedbávána, ač je s podivem, kolik nového v ní lze objevit. Viz Toepell (1986, s. 116).

13 Dedekind (1888, s. 344). 
„Co je to za ,věci‘? To nevíme a ani vědět nemáme, dokonce by bylo nepřístojné po tom pátrat. Jediné, co máme právo vědět, je to, o čem nás poučují axiomy, např. tento:

dva různé body určují vždy jednu přímku [...]“14

Toto pojetí mělo také za následek, že se při záměně všech výskytů určitého základního pojmu, třeba slova bod, za jakékoliv jiné slovo, původní teorie nezmění. Užít by přitom bylo možné i zcela vymyšlená slova, která dosud postrádala smysl, což Dedekind navrhoval již roku 1876 v dopise Lipschitzovi jako vhodný prostředek pro analýzu bezespornosti té které teorie (jmenovitě např. Eukleidovy geometrie či reálných čísel):

„[...] nahradit všechny umělé výrazy libovolnými nově vymyšlenými (dosud bezvýznamnými) slovy, je-li budova dobře zkonstruována, nesmí toto zapříčinit její zřícení [...] “15

Ač se tyto Hilbertem stanovené axiomy navenek velmi podobají axiomům a postulátům Eukleidovým či základním větám Paschovým, na významové úrovni se od nich výrazně odlišují. Tyto axiomy jsou implicitními definicemi ${ }^{16}$ zmíněných základních pojmů (systémů věcí), které se v nich vyskytují, ale také Hilbertem používaných základních vztahů incidence, uspořádání (bytí mezi) a shodnosti. Např. výše uvedený axiom je tak částí implicitní definice bodu, přímky a vztahu incidence. Zcela definován, bráno z druhé strany, je totiž určitý základní pojem či vztah teprve skrze všechny axiomy, ve kterých se vyskytuje. Jeho význam je tedy ovlivněn tím, které axiomy jsme zavedli a které ne. Pro Hilberta je pak to, že je takový systém věcí vůbec možný (tj. že věci existují), zaručeno důkazem bezespornosti takto arbitrárně stanoveného systému axiomů (viz následující odstavec a kapitolu Vliv axiomatiky).

14 Poincaré (1904, s. 29).

15, „[...] alle Kunstausdrücke durch beliebige neu erfundene (bisher sinnlose) Worte zu ersetzen, das Gebäude darf, wenn es richtig construirt ist, dadurch nicht einstürzen [...]“ Dedekind (1876, s. 479).

16 Více k tématu viz např. Weyl (1944, s. 264). Ve francouzském prostředí místo termínu définitions implicites (např. Dubucs (1992, s. 217)) používal H. Poincaré též termín définitions deguisées (doslova převlečené definice). Jiř́ Fiala jej v soudobém sborníku Poincarého textů přeložil jako skryté definice (viz Fiala (2010a, s. 65, 85, 170) vůči originálům Poincaré (19o8, s. 131, 185) a Poincaré (1912, s. 503)), dříve jako maskované definice (viz Fiala (2010b, s. 193) vưči originálu Poincaré (1891, s. 773)). 
Na rozdíl od svých předchůdců uspořádal Hilbert své axiomy geometrie do skupin, a to následovně: axiomy incidence (I), axiomy uspořádání (II), axiomy shodnosti (III), axiom o rovnoběžkách (IV) a axiomy spojitosti (V). Každá z těchto skupin měla dle Hilberta „vyjadřovat jistá vzájemně související základní fakta o našem názoru. " ${ }^{17}$ Systém axiomů měl splňovat tři požadavky: nezávislost, úplnost a bezespornost. Pojem nezávislosti v tomto př́padě znamená, že nelze žádný axiom vyvodit z axiomů ostatních. ${ }^{18} \mathrm{O}$ úplnosti axiomatického systému mluvíme, pokud je v něm každé tvrzení bud' dokazatelné, nebo vyvratitelné. ${ }^{19}$ Pokud je nějaké tvrzení současně dokazatelné i vyvratitelné, je teorie sporná, pokud se takové tvrzení nevyskytuje, je bezesporná, neboli konzistentní. Právě důkaz vzájemné bezespornosti axiomů označuje Hilbert na Mezinárodním kongresu matematiků v Paříži v roce 1900 za nejdůležitější ze všech problémů, které se na poli axiomů vyskytují. ${ }^{20}$ Předtím, než představíme Hilbertův důkaz bezespornosti, se však blíže zaměříme na problém spojitosti.

\section{Axiomy spojitosti}

Mezi axiomy spojitosti patří Archimédův axiom (V1) a axiom úplnosti (V2). Archimédův axiom V1 vypovídá o tom, že pokud na př́ímce, na níž leží tři různé body, klademe kratší úsečku, kterou vytínají dva z nich, několikrát za sebou směrem $\mathrm{k}$ bodu třetímu, vždy se po určitém počtu kroků dostaneme za něj. Tento axiom je ale pouze nutnou podmínkou spojitosti, nikoliv postačující.

Axiom úplnosti ${ }^{21}$ V2 vyjadřuje, že sjednocený systém bodů, přímek a rovin (původně tř́i různých systémů věcí) se nemůže rozšiřovat o další systém věcí tak, že by zároveň v takto rozšířeném systému platily před-

17, „... jede Gruppe] drückt gewisse zusammengehörige Grundtatsachen unserer Anschauung aus." Hilbert (1923, s. 2).

18 Srov. pozn. 5 .

19 Srov. pozn. 21.

20 Hilbert (1900a, s. 300).

21 Stejně jako v případě nezávislosti (viz pozn. 5) může i v případě úplnosti nastat nedorozumění kvůli terminologii. Tento axiom úplnosti V2 vyjadřuje úplnost systémů věcí (tedy základních prvků - bodů, přímek, rovin). Oproti tomu jsme se výše (text u pozn. 19) zmiňovali o úplnosti systému axiomů. Axiom V2 o ní nevypovídá a ani jeho výskyt tuto vlastnost neovlivňuje. 
chozí axiomy I-V1. ${ }^{22} \mathrm{~V}$ tomto ohledu jej lze, v odpovídající podobě, použít i jako poslední axiom jakéhokoliv jiného axiomatického systému. ${ }^{23}$ Pro příslušný spojený systém věcí, v našem případě pro geometrii, proto tento axiom zaručuje jednoznačnost, ale především spojitost. Hilbertův student a pozdější kolega Paul Bernays (1888-1977) poznamenává, že ze znění axiomu úplnosti není na první pohled zřejmé, že vyjadřuje také požadavek spojitosti a že je tento zřejmější např. z Cantorova axiomu, jímž se zavádějí reálná čísla jako posloupnosti vnořených intervalů. ${ }^{24}$

Zmínili jsme také výše, že se axiom spojitosti vyskytoval už u Pasche. Byl zde však jinak formulován než u Hilberta, a to v takové podobě, která byla ekvivalentní k oběma axiomům V1 a V2. Spojitost proto skutečně vyjadřoval. Hilbert nejprve Paschovu formulaci převzal a axiom spojitosti v tomto tvaru uvedl ve výše zmíněném dopise Kleinovi z roku 1894. V prvním vydání Grundlagen der Geometrie byl uveden pouze Archimédův axiom jako jediný axiom spojitosti. Šlo ale o Hilbertovu chybu, na kterou jej upozornil teprve recenzent. V následujících vydáních se již vyskytují oba axiomy spojitosti V1 a V2.

Původně se Archimédův axiom nacházel již v Eukleidových Základech ve formě tvrzení (kniha V, tvrzení 4). Axiom V2 se v Eukleidových Základech nenacházel. ${ }^{25}$ Hilbert proto geometrií eukleidovskou ${ }^{26}$ nazýval ve své knize takovou geometrii, kterou lze odvodit již z axiomů I-V1. Jak bude níže vysvětleno, takovýchto eukleidovských geometrií najde-

22 Přítomnost Archimédova axiomu V1 (nebo odpovídajícího axiomu) vyžaduje Hilbert výslovně. Geometrii, která splňuje jen axiomy I-IV, avšak nesplňuje V1, lze totiž vždy rozšiřovat o další body, aby ony axiomy I-IV zůstaly v platnosti, což je se smyslem axiomu V2 v rozporu. Viz Hilbert (1923, s. 22f). To dokazuje, jinými slovy řečeno, že Archimédův axiom V1 je na těchto axiomech I-IV a V2 závislý. Pouze na axiomech I-IV však závislý není, což Hilbert dokázal ve druhé kapitole Grundlagen modelem geometrie, ve které tyto axiomy I-IV platí, axiomy V1 a V2 však neplatí. Tato geometrie se nazývá nearchimédovská. Ohledně nezávislosti axiomu úplnosti V2 viz níže v textu. Viz Hilbert (1923, s. 29-31).

23 Sám Hilbert jej poprvé použil až při své axiomatizaci aritmetiky, která následovala až po jeho axiomatizaci geometrie. Stalo se tak v přednášce Über den Zahlbegriff z podzimu 1899, tedy mezi prvním a druhým (již opraveným) vydáním díla Grundlagen der Geometrie. Tuto přednášku publikoval Hilbert o rok později jako článek. Viz Hilbert (190ob, s. 240).

24 Bernays (1970, s. 197f).

25 Ani žádná jeho alternativa, kterou by se zaručovala spojitost geometrie (viz pozn. 2), tj. kromě zmíněného Cantorova axiomu např. axiom Dedekindův (viz pozn. 28).

26 Stanovme následující konvenci: pokud budeme hovořit o eukleidovské geometrii v Hilbertově terminologii, nikoliv o eukleidovské geometrii v běžném chápání tohoto pojmu, vyznačíme ji kurzívou. 
me nekonečné množství a až na tu, ve které platí navíc V2, jsou všechny nespojité. Tento speciální případ eukleidovské geometrie o axiomech I-V2, která zároveň odpovídá naší běžné analytické geometrii, nazýval Hilbert geometrií kartézskou. Zároveň poznamenal, že ačkoliv axiom V2 neobsahuje bezprostředně žádný výrok o pojmu konvergence, lze v kartézské geometrii dokázat existenci meze, odpovídající Dedekindovu ře$\mathrm{zu},{ }^{27}$ čímž mínil dělicí bod z Dedekindova axiomu. ${ }^{28}$

\section{Aritmetický model pro důkaz bezespornosti}

Po stanovení systému axiomů geometrie v první kapitole představuje Hilbert v kapitole druhé do̊kaz jejich bezespornosti prostřednictvím konstrukce aritmetického modelu. ${ }^{29}$ Pro jistotu nejprve uved'me, že standardní geometrická interpretace systému axiomů geometrie, ve které jsme intuitivně zvyklí uvažovat o stanovených systémech věcí, jakožto o skutečných bodech, přímkách a rovinách, je v Hilbertově pojetí taktéž pouhým logickosémantickým modelem na stejné úrovni jako kterýkoliv jiný.

V aritmetickém modelu uvažujeme pod oněmi věcmi, které nazýváme „body“, pouze jejich kartézské souřadnice, tj. uspořádané dvojice čísel $(x, y)$, a pod věcmi, které nazýváme „přímkami“, uspořádané trojice čísel ( $m: n: s)$, kde $m$ a $n$ nejsou zároveň nula.$^{30} \mathrm{O}$ třetím systému věcí, „rovinách“, zde Hilbert nemluví. Uvedený aritmetický model tvoří jen

27 Hilbert (1923, s. 23). Dedekind zkonstruoval množinu reálných čísel pomocí tzv. řezů. Termín Dedekindův řez označuje dvě disjunktní množiny racionálních čísel, jejichž sjednocení dá celou množinu racionálních čísel, a je též ztotožňován s číslem, které toto rozdělení zapř́íčiňuje. To však může být jak racionální, tak iracionální. Množina všech takových čísel bude množinou čísel reálných. Viz Epple (1999, s. 379f).

28 „Rozdělíme-li všechny body přímky na dvě třídy tak, že každý bod první třídy leží vlevo od každého bodu druhé tř́idy, potom existuje jeden a právě jeden bod, který dělí všechny body na tyto dvě třídy, tedy bod, ve kterém je přímka na tyto dvě části rozstřižena.“ Dedekind (1872, s. 322). Důvodem, proč Hilbert namísto tohoto postulátu použil pro zajištění spojitosti dvojici axiomů (V), byla dle interpretace Halletta a Majera jeho úzká provázanost s aritmetickým světem. Hilbert se snažil vybudovat svou geometrii bez použití pojmu čísla. Viz Hallett \& Majer (2004, s. 430); srov. níže v textu kapitolu Hilbertovy důvody.

29 U Hilberta neručí za bezespornost eukleidovské geometrie pouhý názor, na rozdíl od Paschových a Eukleidových axiomů. Hilbert se opře o bezespornost aritmetiky.

30 Výraz „bod leží na přímce“, který se vyskytuje v axiomech, bude v tomto pojetí znamenat, že čísla $x, y, m, n, s$ vyhovují jisté rovnici: $m x+n y+s=0$. Body $(x, y)$ pak budou ležet na přímce $(m: n: s)$. Viz Hilbert (1923, s. 24). 
pro dvojrozměrnou geometrii a poznamenává pouze, že rozššření do třetího rozměru by již nebylo obtížné.

Pro uvedeným způsobem pozměněnou interpretaci základních pojmů mají být nyní stanovené axiomy I-V2 splněny. Dosazujeme-li za ony proměnné $x, y, m, n, s$ reálná čísla, platnost axiomů ověříme snadno. ${ }^{31}$ Zároveň tím s odvoláním na bezespornost aritmetiky reálných čísel podáváme důkaz bezespornosti geometrie o uvedených axiomech I-V2, tj. geometrie kartézské dle Hilbertovy terminologie. ${ }^{32}$

Hilbert však ve druhé kapitole Grundlagen postupoval jinak. Nejprve konstruoval aritmetický model pro důkaz bezespornosti libovolné geometrie eukleidovské, tj. model, ve kterém jsou splněny zatím jen axiomy I-V1. Samozřejmě, jestliže náš model, ve kterém jsme za proměnné $x, y, m, n, s$ dosazovali reálná čísla, splňoval axiomy I-V2, splňoval i axiomy I-V1. Ptejme se však s Hilbertem nově: Lze za ony proměnné dosazovat i výběrem z nějaké užší množiny? Pokud ano, která množina bude ta nejmenší možná? Může jít např. jen o čísla celá?

Předně, jak vyžaduje Archimédův axiom V1, tato množina musí být nějakým algebraickým tělesem, tj. strukturou, která obsahuje výsledky operací sčítání a násobení u všech dvojic svých prvků. Toto těleso musí být dále archimédovské, tj. uspořádané a s tou vlastností, že při zvolení libovolných dvou prvků lze násobením menšího z nich nějakým celým číslem vždy získat číslo, které bude větší než číslo druhé. To by např. racionální čísla splňovala, nepodařilo by se nám však na nich ověřit axiomy shodnosti III, které kromě přenášení úseček a úhlů umožňují také provádění shodných zobrazení, tj. geometrických operací posunutí, osové souměrnosti či rotace. Výsledkem naposledy jmenované operace rotace $\mathrm{v}$ aritmetickém modelu s racionálními čísly by totiž již mohl být i bod o iracionálních souřadnicích. Při konstrukci hledaného tělesa tedy

31 Axiomy incidence I tím, že bod a přímka vyhovují rovnici z předchozí poznámky, axiomy uspořádání II tím, že je těleso reálných čísel uspořádané, axiomy shodnosti III, které umožňují provádění geometrických operací (viz níže), tím, že souřadnice bodu po jejich provedení budou opět reálné, axiom o rovnoběžkách IV tím, že pro danou přímku $(m: n: s)$ a daný bod $A_{0}\left[x_{o}, y_{0}\right]$ mimo ni existuje jediná prímka $(m: n: t)$, splňující rovnici $m x_{o}+n y_{o}+t=o$, aby zároveň žádný bod $A[x, y]$, který vyhovuje $m x+n y+t=o$, nevyhovoval současně rovnici pro původně danou přímku $(m: n: s)$, tj. $m x+n y+s=o$. Nakonec jsou splněny i axiomy spojitosti: Archimédův axiom V1 proto, že jsou reálná čísla archimédovským tělesem, a axiom úplnosti V2 proto, že množinu reálných čísel nelze při zachování předchozích axiomů rozšiřovat o jakákoliv další č́sla.

32 Říkáme pak, že reálná č́sla indukují kartézskou geometrii. 
musíme kromě všech aritmetických operací, nutných pro konstrukci tělesa racionálních čísel, tj. sčítání, odčítání, násobení, dělení, přidat navíc operaci odmocniny ze součtu čtverců, zkráceně $\sqrt{1+\omega^{2}}$, kde symbol $\omega$ značí prvek, který již v tělese je. ${ }^{33}$

Takto zkonstruované těleso indukuje nejmenší možnou eukleidovskou geometrii, ve které jsou splněny všechny axiomy I-V1. Každé její rozšíření o další body potom bude $\mathrm{v}$ aritmetickém modelu znamenat i rozšíření příslušného algebraického tělesa. Maximálním takovým rozšírením je kartézská geometrie a jí příslušné těleso reálných čísel. Hilbert kapitolu zakončuje takto:

„Lze nahlédnout, že existuje nekonečně mnoho geometrií,
které vyhovují axiomům I-V1, oproti tomu jen jedna jediná,
totiž geometrie kartézská, ve které platí zároveň axiom úpl-
nosti V2.“34

K tématu patří i metoda, kterou Hilbert uvedl až na konci kapitoly třetí po redefinici Eukleidovy nauky o proporcích, pro jednoznačné přiřazení reálných čísel (ne nutně všech) všem bodům dané přímky (v příslušné eukleidovské, tj. i nespojité, geometrii). ${ }^{35}$

33 Výsledné těleso, Hilbertem označované jako $\Omega$, je menší než těleso reálných čísel a je oproti němu spočitatelné. Zároveň je i menší než Dedekindem navržené těleso algebraických čísel, které původně použil Dedekind pro ukázání nespojitosti eukleidovské geometrie, a Hilbert tak tímto tělesem $\Omega$ Dedekindovu podmínku zpřesňuje. Viz Hilbert (1923, s. 24ff); srov. Dedekind (1888, s. 339). O konstrukci tohoto tělesa v Hilbertových Grundlagen referoval též Jiří Fiala, viz Fiala (2011, s. 22). Východiskem mu však byly geometrické konstrukce pravítkem a etalonem, uvedené až na konci díla v sedmé kapitole.

34 Hilbert (1923, s. 26).

35 Na př́mce stanovíme dva body a označíme je o a 1. Potom budeme výslednou úsečku stále půlit a v každém kroku přiřadíme příslušnému bodu číslo $\frac{1}{2^{n}}$. Úsečku mezi počátkem a tímto bodem značí Hilbert $O \frac{1}{2^{n}}$. Nanášíme-li ji za sebou směrem k bodu 1, přriřadíme výsledným bodům hodnoty $\frac{m}{2^{n}}$, a nanášíme-li ji na opačnou stranu, přiřazujeme hodnoty $-\frac{m}{2^{n}}$. Viz Hilbert (1923, s. 51).

Tato metoda vyžaduje Archimédův axiom V1, který zaručuje, že se v rozvoji zlomků $\frac{1}{2^{n}}$ body nenahustí ještě na jiném místě přímky než u počátku, a tedy, že číslo o nebude přiděleno dvěma různým bodům (viz nestandardní analýza). Více k tématu viz Toepell (1986, s. 70ff). Zavedení nebo nezavedení axiomu úplnosti V2 potom rozhoduje o tom, zda lze také opačným směrem přiřadit bod všem reálným číslům. To lze provést pouze v geometrii kartézské.

Pro zajímavost poznamenejme, že Hilbert toto téma ve zmíněných předchozích přednáškách z roku 1898/1899 uvedl úryvkem z dramatu Gottloba E. Lessinga (1729-1781) Moudrý Nathan, pojednávajícím o tom, že největším divem ze všech je, že nám jsou skutečné divy skryty ve své všednosti. Hilbert zmínil následně klíčovou roli, kterou hraje obyčejné číslo v přírodních vědách. Viz Toepell (1986, s. 194). 
To, že se Hilbertovi pro zmíněné geometrie (jak kartézské o axiomech I-V2, tak eukleidovských o axiomech I-V1) podařilo nalézt aritmetické modely, $\mathrm{v}$ nichž byly příslušné axiomy splněny, zároveň podle něj dokazovalo, že jsou tyto geometrie bezesporné. Především v př́ípadě geometrií eukleidovských to pro jejich nespojitost nebylo vủbec samozřejmé, a tento Hilbertův počin tak nelze považovat za výhradně formální.

Kromě uvedeného důkazu bezespornosti celého axiomatického systému využil Hilbert v druhé kapitole aritmetické modely i v důkazech nezávislosti jednotlivých skupin axiomů. Důkaz nezávislosti axiomů spojitosti (V) prritom navíc zahrnoval popis nových nearchimédovských geometrií, tvořených pouze axiomy I-IV, tj. takových, kde oproti výše uvedeným př́íladům na neplatnost axiomu úplnosti V2 již neplatí ani Archimédův axiom V1. ${ }^{36}$

\section{Hilbertovy důvody}

Standardním výkladem hlavního důvodu pro vznik Hilbertova díla je, že v něm chtěl Hilbert vyjasnit vzájemné logické závislosti mezi hlavními větami eukleidovské geometrie, a tento cíl měl Hilbert sledovat i uvedením svého vlastního, nového systému axiomů, které měly být podány v co nejpřehlednějším a nejvhodnějším tvaru. Tento systém měl zjednodušit systém Eukleidův a zacelit jeho nedostatky. ${ }^{37}$ Podle Hermanna Weyla chtěl Hilbert ve svém díle především obrátit trend nastolený Peanem a Veronesem, jejichž výstavba geometrie byla kvůli značné snaze o minimalizaci počtu nedefinovaných pojmů velmi obtížně srozumitelná. Stanovením bodů, přímek a rovin za základní pojmy a stanovením incidence, uspořádání (bytí mezi) a shodnosti za základní vztahy měl Hilbert významně napomoci svým čtenářům k pochopení svého díla, nebot’ se tím zcela záměrně přiklonil k tradici, všem dobře známé z Eukleidových Základů. ${ }^{38}$

36 Nearchimédovské geometrie označil Poincaré za Hilbertovu nejoriginálnější koncepci. Hilbert se však v Grundlagen der Geometrie odkazuje v souvislosti s nimi již na předchozí výzkumy Veroneseho. Viz Poincaré (1903, s. 10), Veronese (1884).

37 Viz např. Epple (1999, s. 401).

38 Srov. Weyl (1944, s. 265); Reid (1970, s. 60). 
Pro porozumění Hilbertovým motivacím je však nutné zmínit, čeho si všiml Felix Klein. Při porovnání Grundlagen der Geometrie se záznamy dřívějších Hilbertových přednášek je zřetelné, že se Hilbertovy důvody pro novou axiomatizaci geometrie měnily v čase. Dle Kleina bylo konečným Hilbertovým cílem vyjasnění situace ohledně axiomů spojitosti. ${ }^{39} \mathrm{~K}$ tomuto názoru se přikláníme nejvíce a propojení mezi spojitostí a bezesporností v Hilbertově pojetí jsme se výše v tomto článku pokusili objasnit.

Dle Blumenthala bylo Hilbertovým cílem vybudovat úplnou axiomatiku zcela mimo nauku o celých číslech, což mu mělo sloužit jako argument proti pojetí Leopolda Kroneckera (1821-1891), podle něhož jednoznačně existují pouze celá kladná čísla a z ostatních matematických objektů mají mít legitimní platnost jen ty, které lze z celých čísel v konečném počtu kroků zkonstruovat. ${ }^{40}$ Geometrie měla být pro tento Hilbertův záměr tím nejpřístupnějším oborem. K této interpretaci však poznamenejme, že ačkoliv při stanovování axiomů geometrie číslo vskutku zavedeno nebylo, při dokazování bezespornosti geometrie se Hilbert přesto o aritmetiku opírá.

Hilbert přitom pokládá založení geometrie za obtížnější než založení aritmetiky. O teorii čísel a jejím vztahu k ostatním oborům se ve své předmluvě k Zahlbericht z roku 1897 vyjadřuje takto:

„[...] jednoduchost jejích základo̊n, přesnost jejích pojmů a čistota jejích pravd; tyto vlastnosti jí náležejí od začátku, zatímco ostatní matematické vědní obory musely projít kratším nebo delším vývojem, než byly všude splněny požadavky na jistotu v pojmech a přísnost v důkazech." 41

Hilbert dále v textu uvádí, že cílem moderní aritmetizace geometrie, kterou zapříčinily výzkumy neeukleidovské geometrie, je zpřísnění geometrických důkazů pomocí co nejpřímějšího zavedení čísla.

39 Klein (1968, 2. díl, s. 200); více k tématu viz Toepell (1986, s. 199).

40 Blumenthal (2012, s. 176); srov. Blumenthal (1970, s. 391); více k tématu viz Ewald (2006, S. 942).

41 „[...] die Einfachheit ihrer Grundlagen, die Genauigkeit ihrer Begriffe und die Reinheit ihrer Wahrheiten; ihr kommen diese Eigenschaften von Hause aus zu, während andere mathematische Wissenszweige erst eine mehr oder minder lange Entwicklung haben durchmachen müssen, bis die Forderungen der Sicherheit in den Begriffen und der Strenge in den Beweisen überall erfüllt worden sind." Hilbert (1897, s. 63). 


\section{Vliv axiomatiky}

Axiomy v Hilbertově pojetí nebyly založené na názoru, jako axiomy Eukleidovy či Paschovy, a nebyly tak chápány jako evidentně pravdivá tvrzení, která mají oporu v reálném světě. Představovaly oproti tomu množinu nedokázaných, ale vždy pravdivých vět, kterou při budování jisté abstraktní teorie stanovuje autor zcela libovolně, pokud jen jsou jednotlivé axiomy vzájemně bezesporné. $V$ Hilbertově pojetí pak za předpokladu důkazu bezespornosti axiomů vždy existují také ony základní pojmy, tj. systémy věcí, které jsou prostřednictvím axiomů implicitně definovány. Hilbert tak obrátil dosavadní vztah mezi existencí a bezesporností, čímž se zapsal poprvé do dějin logiky. Jelikož implicitní definice neobjasňovaly, co konkrétně jednotlivé systémy věcí označují a zda vůbec něco, byly tyto definice ontologicky neutrální, což bylo v souladu s dobovým trendem neutralizovat metafyzické otázky v matematice. ${ }^{42}$ Hilbert je proto nyní znám i v dějinách filosofie.

Po vydání Grundlagen der Geometrie se s Hilbertem na toto téma přel logicista Gottlob Frege (1849-1915).43 Hilbert držel stanovisko, že matematika je dána nezávisle na logice a vyžaduje některé matematické objekty, které leží mimo logiku. Ty je nutné postulovat a v axiomech, tj. jejich implicitních definicích, uvést všechny požadované vlastnosti. V návaznosti na uvedenou korespondenci s Fregem si Hilbert utvrdil své stanovisko roku 1904 v přednášce Über die Grundlagen der Logik und der Arithmetik na univerzitě v Heidelbergu. Hilbert požaduje, aby ani jeden z obou oborů nebyl zahrnován pod druhý, ale aby se usilovalo o jejich paralelní rozvoj. ${ }^{44}$

\section{Závěr}

V tomto článku jsme vysvětlili Hilbertovo pojetí aritmetizace geometrie jako prostředku pro důkaz její bezespornosti. Podmínkou k tomu bylo zavedení axiomatizace, tedy stanovení nového systému axiomů pro ge-

42 Viz např. Epple (1999, s. 401).

43 Dubucs (1992); viz Epple (1999, s. 407); srov. Bedürftig \& Murawski (2015, s. 98).

44 Hilbert (1904); srov. Trlifajová (2010, s. 96f, 99f); dále též Vopěnka \& Větrovcová (2015, s. 204) a Epple (1999, s. 403, 410). 
ometrii tradovanou od Eukleidových Základů. Uvedli jsme, že tato geometrie, též běžně nazývaná eukleidovská, je za nutně spojitou pouze považována, ale ve skutečnosti nemusí některé body vůbec obsahovat. Proto Hilbert zavádí rozlišení mezi geometrií eukleidovskou a geometrií kartézskou, která představuje její speciální případ jakožto jediná spojitá eukleidovská geometrie. Aritmetizace geometrie tak Hilberta vedla k zavedení zobecněných spojitých pojmů, jako např. přímka, na podkladě původně diskrétního číselného oboru. Teprve aritmetizace geometrie kartézské bude převodem na spojitou aritmetiku reálných čísel.

Můžeme si položit otázku, zda formalistická matematika, která není založena na názoru a která povede až k digitalizaci, neklade chybný obecný standard. ${ }^{45}$ Důsledky tohoto pojetí matematiky, jichž si Hilbert všiml, jej mohly vést k tomu, aby ve svých přednáškách Anschauliche Geometrie z roku 1920/192146 zaujal diametrálně opačné stanovisko a představil studentům geometrii, která nebyla redukována na dokonale přesné věty, ale byla zato pro studenty snadněji pochopitelná díky svému založení v názoru, analogicky jako u geometrií z děl Pasche či Eukleida. ${ }^{47} \mathrm{~V}$ té době však sám pokračoval v práci na abstraktní teorii důkazu. Proto se domníváme, že oba tyto známé Hilbertovy př́íspěvky k filosofii matematiky a formální logice, tj. formalismus i teorie důkazu, mají své kořeny již při hledání axiomatizace a aritmetizace geometrie v Grundlagen der Geometrie.

\section{Literatura}

Bečvář, J. \& Bečvářová, M., eds. (2011): 32. mezinárodní konference historie matematiky, Jevíčko, 26. 8. až 30. 8. 2011. Matfyzpress, Praha.

Bedürftig, T. \& Murawski, R. (2015): Philosophie der Mathematik. De Gruyter, Berlin.

45 Srov. Fiala (2005, s. XXXIX).

46 Hilbert \& Cohn-Vossen (1996).

47 Srov. Poincaré (1904, s. 32f). 
Benis-Sinaceur, H., ed. (2008): R. Dedekind: La création des nombres. Vrin, Paris.

Bernays, P. (1970): „Hilberts Untersuchungen über die Grundlagen der Arithmetik." In Hilbert (1970, sv. 3): 196-216.

Blumenthal, O. (1970): „Lebensgeschichte.“ In Hilbert (1970, sv. 3): $388-429$.

Blumenthal, O. (2012): „David Hilbert.“ Mitteilungen der Deutschen Mathematiker-Vereinigung 20 (3): 175-180. DOI: 10.1515/ dmvm-2012-0072.

Dedekind, R. (1872): „Stetigkeit und irrationale Zahlen.“ In Fricke \& Noether \& Öystein (1932, sv. 3): 315-332.

Dedekind, R. (1876): „Aus den Briefen an R. Lipschitz.“ In Fricke \& Noether \& Öystein (1932, sv. 3): 464-482.

Dedekind, R. (1888): „Was sind und was sollen die Zahlen?“ In Fricke \& Noether \& Öystein (1932, sv. 3): 335-391.

Dubucs, J. (1992): „Correspondence Frege / Hilbert (1900).“ In Rivenc \& Rouilhan (1992): 215-220.

Epple, M. (1999): „Grundlagen der Analysis 1860-1910.“ In Jahnke (1999): 388-429.

Ewald, W., ed. (2006): From Kant to Hilbert: a source book in the foundation of mathematics. Clarendon Press, Oxford.

Fiala, J. (2005): Analytická filosofie - úvod. OPS, Plzeň.

Fiala, J. ed. (2010a): H. Poincaré: Č́slo - prostor - čas. OPS, Kanina.

Fiala, J. (2010b): „Henri Poincaré a filosofie vědy.“ In Fiala (2010a): 179-214.

Fiala, J. (2011): „Papírová geometrie v devíti jednáních.“ In Bečvář \& Bečvářová (2011): 11-32.

Frege, G. (1884): Die Grundlagen der Arithmetik, eine logisch-mathematische Untersuchung über den Begriff der Zahl. Koebner, Breslau.

Frege, G. (1893): Die Grundgesetze der Arithmetik Begriffsschiftlich abgeleitet. H. Pohle, Jena.

Fricke, R. \& Noether, E. \& Öystein, O., eds. (1932): Richard Dedekind Gesammelte mathematische Werke. Vieweg, Braunschweig. 
Hallett, M. \& Majer, U., eds. (2004): David Hilbert - Lectures on the Foundation of Geometry. Springer, Heidelberg - Berlin - New York.

Hilbert, D. (1895): „Über die gerade Linie als kürzeste Verbindung zweier Punkte." In Hilbert (1923): 112-118.

Hilbert, D. (1897): „Die Theorie der algebraischen Zahlenkörper.“ In Hilbert (1970, sv. 1): 63-349.

Hilbert, D. (1900a): „Mathematische Probleme.“ In Hilbert (1970, sv. 3): $290-329$.

Hilbert, D. (190ob): „Über den Zahlbegriff.“ In Hilbert (1923): 237242.

Hilbert, D. (1904): „Über die Grundlagen der Logik und der Arithmetik." In Hilbert (1923): 243-258.

Hilbert, D. (1923): Grundlagen der Geometrie. (6. vydání, originál 1899). Teubner, Leipzig.

Hilbert, D. (1970): Gesammelte Abhandlungen. (2. vydání, originál 1930). Springer, Berlin.

Hilbert, D. \& Cohn-Vossen, S. (1996): Anschauliche Geometrie. (2. vydání, originál 1932). Springer, Berlin.

Jahnke, H. N., ed. (1999): Geschichte der Analysis. Spektrum, Heidelberg.

Klein, F. (1871): „Über die sogenannte Nicht-Euklidische Geometrie.“ Mathematische Annalen 4 (4): 573-625.

Klein, F. (1873): „Über die sogenannte Nicht-Euklidische Geometrie.“ Mathematische Annalen 6 (2): 112-145.

Klein, F. (1968): Elementarmathematik von höheren Standpunkte aus. (3. vydání, originál 1908). Teubner, Leipzig

Pasch, M. (1882): Vorlesungen über neuere Geometrie. Teubner, Leipzig.

Peano, G. (1889): I principii di geometria, logicamente esposti. Bocca, Torino.

Peano, G. (1894): „Sui fondamenti della geometria.“ In Opere Scelte 3, G. Peano, Roma, 1959, s. 115-157. 
Poincaré, H. (1891): „Les géometries non euclidiennes.“ Rév. Gén. Sci.

Pures et Appl. 2 (23): 769-774.

Poincaré, H. (1903): „Review of Hilbert's ,Foundations of Geometry“ “

Bulletin of the American Mathematical Society 10 (1): 1-23.

Poincaré, H. (1904): „Matematické definice a vyučování.“ In Fiala (2010a): 25-44.

Poincaré, H. (1905): „Nové logiky.“ In Fiala (2010a): 75-90.

Poincaré, H. (1908): Science et méthode. Flammarion, Paris.

Poincaré, H. (1912): „Pourquoi l'espace a trois dimensions.“ Revue de métaphysique et de morale 20 (4): 483-504.

Reid, C. (1970): Hilbert. Springer, Heidelberg - Berlin - New York.

Rivenc, F. \& Rouilhan, P. (1992): Logique et fondements des mathématiques - Anthologie (1850-1914). Payot, Paris.

Russell, B. (1902): „Letter to Frege.“ In Van Heijenoort (1967): 122123.

Toepell, M. (1986): Über die Entstehung von David Hilberts „Grundlagen der Geometrie“. Vandenhoeck \& Ruprecht, Göttingen.

Trlifajová, K. (2011): „Logika jako matematizace myšlení.“ In Spor o matematizaci světa, eds. P. Kůrka \& A. Matoušek \& B. Velický, Pavel Mervart, Červený Kostelec, 2011, s. 86-102.

van Heijenoort, J., ed. (1967): From Frege to Gödel. Harvard University Press, Cambridge.

Večerka, K. (1967): „Bernard Bolzano, Anti-Euklid.“ In Sborník pro dějiny př́rodních věd a techniky, sv 11, ed. K. Večerka, Nakladatelství Československé akademie věd, Praha, 1967, s. 201-216.

Veronese, G. (1894): Grundzüge der Geometrie. Teubner, Leipzig. Vopěnka, P. (2004): Vyprávění o kráse novobarokní matematiky. Práh, Praha.

Vopěnka, P. \& Větrovcová, M. (2015): Uvedení do obecné topologie a jejích dějin do roku 196o. Vyšehrad, Praha.

Weyl, H. (1944): „David Hilbert and His Mathematical Work.“ In Reid (1970): 245-284. 


\begin{abstract}
Hilbert's arithmetisation of geometry

In this article, we describe how David Hilbert (1862-1943) understood the arithmetisation of geometry in the book Grundlagen der Geometrie from 1899. First, we introduce Hilbert's forerunners from the same period who were either asking for changes in the foundations of geometry or implemented them by axiomatic-deductive method, and we do not omit the work included in Hilbert's previous lectures. Further, we try to explain the contents of the first two chapters of the book and present the context which is necessary to understand them. We present the implicit definitions of the elementary notions and relationships in the axioms and Hilberts division of the axioms into groups. We focus more on the axioms of continuity in context with the problem of the consistency of particular geometries by describing the construction of the arithmetical model of the axioms of geometry that Hilbert uses for the consistency proof. At the end, we strive to show Hilbert's main intentions for writing the book and we mention some of the implications of his treatment.
\end{abstract}

Zeman, J. (2018): „Hilbertova aritmetizace geometrie“ Filosofie dnes 10(1): 4563. Dostupné z www.filosofiednes.ff.uhk.cz 